\title{
Callus Formation and Shoot Regeneration as Affected by Plant Growth Regulators and Explant Types in Three Strawberry Cultivars (Fragaria $x$ ananassa Duch.). \\ Dawa, K. K. ${ }^{1}$; M. E. El-Denary ${ }^{2}$ and I. M. Abo-Elglagel ${ }^{2}$ \\ ${ }^{1}$ Vegetables and Ornamental Dept., Faculty of Agriculture, Mansoura University, Mansoura, Egypt. \\ ${ }^{2}$ potato and Vegetatively propagated Veget. Dept., Hort. Res. Inst., Agric. Res. Center, Egypt
}

\section{ABSTRACT}

An experiment was undertaken to find the most appropriate explant type, (i.e., shoot tip, leaf, immature fruit and anther explants) and the appropriate growth regulator concentrations and combinations on callus formation and shoot regeneration in 3 strawberry (Fragaria $x$ ananassa Duch.) cultivars, namely Festival, Fortuna and Sweet Charlie. As for callus formation in response to growth regulators, ten combinations between 2, 4-dichlorophenoxyacetic acid (2, 4-D) and 6-Benzylaminopurine (BAP) were used. significant variances among different media were obtained and $0.5 \mathrm{mg} \mathrm{L}^{-1}$ BAP $+1.5 \mathrm{mg} \mathrm{L}^{-1} 2$, 4-D produced the highest response $(95.75 \%)$ in comparison to other media. Maximum callus formation percentage was obtained the using runner explant $(75.38 \%)$ while immature fruit explant gave the lowest value. Festival and Fortuna cultivars recorded higher percentage of callus formation than Sweet Charlie. Calli derived from the good callus induction medium were tested for shoot regeneration with ten different combinations from BAP and NAA. The results exhibited that using runner as explant source and $2.0 \mathrm{mg} \mathrm{L}^{-1}$ BAP with the three tested cultivars recorded significant regeneration percentage in comparison to other combinations. Keywords: Strawberry cultivars, callus formation, regeneration and explant types.

\section{INTRODUCTION}

Strawberry (Fragaria $\times$ ananassa Duch.) belongs to the Rosaceae family. The strawberry fruit is delicate in flavor, texture, shape, resistant to diseases, and rich in vitamins and minerals (Giampieri et al., 2015 and Karim et al., 2015.

Strawberry cultivated area in Egypt was 15614.4 feddans with production of 283471 tons, and this area is in increasing over the years, and an advanced rank in Egypt's exports to European and Arab markets with an amount of 75,000 tons per year (FAO 2014).

Somaclonal variations have positive and negative impacts in plant breeding. These genetic variabilities lead to the expression of traits such as quality and yield, also resistance to diseases, herbicides and tolerance to environmental or chemical stresses. Furthermore, cases of variants were found in callus-derived plantlets, while could not be detected in plants derived from meristems or via direct leaf regeneration (Karim et al., 2015). Previous studies showed that the concentrations of auxin in culture media and also the number of subcultures are important factor for induction of somaclonal variation in an in vitro system (Gaafar and Saker, 2006). The main aims of this investigation were to find the most appropriate type of explant and to investigate the appropriate growth regulator combinations and concentrations for callus formation and regenerations from shoot tip, leaf, immature fruit and anther explants in three strawberry cultivars to produce new strain.

\section{MATERIALS AND METHODS}

Three strawberry cultivars, namely Festival, Fortuna and Sweet Charlie, kindly provided by Pico Company were grown in the greenhouse of Improvement of the Main Vegetable Crops and Hybrids Production (IMVCHP), Dokky, Horticulture Research Institute, Giza, Egypt. The present study was carried out from 2014 to 2016.

\section{Preparation of plant material:}

Runner tips $(1-1.5 \mathrm{~cm})$ were collected before opening from the greenhouse grown stock plants and washed with tap water having Tween-20 for 20 minutes to disinfect their surfaces. Afterwards, explants were washed several times with sterile distilled water. Surface sterilization was done by dipping the runner in Clorox ${ }^{\circledR}$ $15 \%$ (commercial sodium hypochlorite $5 \%$ ) for $15 \mathrm{~min}$. Parts of terminal buds $(2-3 \mathrm{~mm})$ were separated and cultured on different callus formation media. The other runner were cultured on MS (Murashige and Skoog, 1962) medium containing $0.1 \mathrm{mg}$ L-1 6-benzylaminopurine (BAP) and $0.1 \mathrm{mg} \mathrm{L}-1$ Gibberellic acid (GA3) and incubated in growth chamber 16/8 light/dark cycle at $25 \pm 2^{\circ} \mathrm{C}$ for 45 days as a source of tested leaves on callus formation smedium. Leaf explants $(0.5 \mathrm{~cm}$ width $)$ were cut from the middle of the leaflet (after laceration the lower surface) and were planted on callus induction medium where the upper surface of the leaf explant was intact the medium. Regarding anther, closed flower buds (1.0-1.2 $\mathrm{mm}$ in length) with containing microspores at the uninucleate stage harvested and were surface sterilized, using 70\% ethanol ( $1 \mathrm{~min}$ ), followed by immersing for 10 min. in a $20 \%$ solution of commercial bleach (Clorox) containing 5\% sodium hypochlorite. After that, flowers were washed three times were sterile distilled water. Anther without filament was cultured on callus formation media. Immature strawberry fruits at two weeks after flowering (1-2 cm length) were obtained from vigorously grown plants. The fruits were surface disinfected by soaking for $30 \mathrm{sec}$. in $70 \%$ ethanol, then in $15 \%$ Clorox for $15 \mathrm{~min}$. and rinsed three times with sterile distilled water. Fruit tissue explants were then cut into $4 \mathrm{~mm}$ cubes and were cultured on callus formation media. . Each treatment contained four replicates (five petri dishes/ each replicate). Then, all Petri dishes containing explant were incubated in the dark at $25 \mathrm{o} \mathrm{C} \pm 2$ for 45 days.

\section{Callus formation medium.}

To study the effects of different combinations and concentrations of 2,4-D and BAP on callus induction, different explants (runner, leaf, anther and immature fruits) of three strawberry cultivars were cultured on 10 different callus formation media (Table 1).

\section{Regeneration stage:}

The effect of different concentrations and combinations of $\mathrm{BAB}+\alpha$-naphthalene acetic acid (NAA), and the source of callus were studied on the ability of shoot regeneration. Each treatment contained 
four replicates (3 petri dishes/ each replicate). Five calli were plated in each Petri dish and were kept at $25^{\circ} \mathrm{c}$ under $16 \mathrm{~h}$ photoperiod and light intensity 2000 lux. using cool white fluorescent lamps for 60 days. The regeneration media are presented in Table (2).

Table 1. Murashige and Skoog media used for callus induction supplemented with different concentrations from BAP and 2, 4-D

\begin{tabular}{|c|c|c|}
\hline Medium code & Auxin & Cytokinin \\
\hline Control (MS) & Free hormone & \\
\hline MS1 & $0.5 \mathrm{mg} \mathrm{L}^{-1} 2,4-\mathrm{D}$ & \\
\hline MS2 & $1.0 \mathrm{mg} \mathrm{L}^{-1} 2,4-\mathrm{D}$ & $+0.2 \mathrm{mgL}^{-1} \mathrm{BAP}$ \\
\hline MS3 & $1.5 \mathrm{mg} \mathrm{L}^{-1} 2,4-\mathrm{D}$ & \\
\hline MS4 & $0.5 \mathrm{mg} \mathrm{L}^{-1} 2,4-\mathrm{D}$ & \\
\hline MS5 & $1.0 \mathrm{mg} \mathrm{L}^{-1} 2,4-\mathrm{D}$ & $+0.5 \mathrm{mgL}^{-1} \mathrm{BAP}$ \\
\hline MS6 & $1.5 \mathrm{mg} \mathrm{L}^{-1} 2,4-\mathrm{D}$ & \\
\hline MS7 & $0.5 \mathrm{mg} \mathrm{L}^{-1} 2,4-\mathrm{D}$ & \\
\hline MS8 & $1.0 \mathrm{mg} \mathrm{L}^{-1} 2,4-\mathrm{D}$ & $+1.0 \mathrm{mgL}^{-1} \mathrm{BAP}$ \\
\hline MS9 & $1.5 \mathrm{mg} \mathrm{L}^{-1} 2,4-\mathrm{D}$ & \\
\hline
\end{tabular}

Table 2. Media used for regeneration of strawberry cultivars and different concentrations and combinations from (BAP, $\alpha$-naphthalene acetic acid NAA).

\begin{tabular}{lcc}
\hline Medium code & \multicolumn{1}{c}{ Cytokinin } & Auxin \\
\hline Control (MS) & Free hormone & \\
\hline MSR1 & $1.0 \mathrm{mg} \mathrm{L}^{-1} \mathrm{BAP}$ & \\
MSR2 & $2.0 \mathrm{mg} \mathrm{L}^{-1} \mathrm{BAP}$ & $+0.1 \mathrm{mgL}^{-1} \mathrm{NAA}$ \\
MSR3 & $3.0 \mathrm{mg} \mathrm{L}{ }^{-1} \mathrm{BAP}$ & \\
\hline MSR4 & $1.0 \mathrm{mg} \mathrm{L}^{-1} \mathrm{BAP}$ & \\
MSR5 & $2.0 \mathrm{mg} \mathrm{L}^{-1} \mathrm{BAP}$ & $+0.5 \mathrm{mgL}^{-1} \mathrm{NAA}$ \\
MSR6 & $3.0 \mathrm{mg} \mathrm{L}^{-1} \mathrm{BAP}$ & \\
\hline MSR7 & $1.0 \mathrm{mg} \mathrm{L}^{-1} \mathrm{BAP}$ & \\
MSR8 & $2.0 \mathrm{mg} \mathrm{L}^{-1} \mathrm{BAP}$ & + Without auxin \\
MSR9 & $3.0 \mathrm{mg} \mathrm{L}^{-1} \mathrm{BAP}$ & \\
\hline
\end{tabular}

After 60 days of culture, the obtained shoots from previous regeneration stage were subcultured on the best obtained regeneration media containing $0.5 \mathrm{mg} \mathrm{L}-1$ GA3 for 4 week.

\section{Statistical analysis:}

Experiments were designed in completely randomized design and the analysis of variance (ANOVA) was performed to test the significance of the differences among treatments according to Duncan (1965).

\section{RESULTS AND DISCUSSION}

\section{Callus formation}

The response of all cultivars and four explants were recorded for ten media after 45 days of incubation. Percentage of callus formation and callus fresh weight per explant were used as parameters for evaluation.

\section{Callus formation percentage}

The mean percentage of callus formation for all cultivars and explant types on ten different media are obtainable in Table (3). The results revealed that the percentage of callus formation varied according to the cultivars, explant types and the used concentration PGRs.

The obtained data revealed that there are significant differences among the cultivars. Festival and Fortuna cultivars recorded higher percentages of callus formation $(71.28 \%$ and $71.22 \%)$ than Sweet Charlie $(69.45 \%)$. This may be due to genotypes. These results are similar to those of, Sutan (2010) and Sutan et al. (2010) who found that different genotypes varied significantly in callus induction.

Regarding the effect of the explants, the obtained data in Table (3) and the photo (1) revealed significant differences among the explant types. As the runner explant recorded the maximum rate $(75.38 \%)$, followed by leaf $(74.30 \%)$ while immature fruit gave the lowest value $(64.075 \%)$. The organ contribution in callus formation percent depended on the endogenous hormones levels or their sensitivity which may differ from one organ to another (Pierik, 1987). Similar results were recorded by Biswas et al. (2010) who found that runner segments and nodal explants produced considerably more callus than did leaf explants, indicating that the source of explant is a substantial factor in determining the rate of success. Many other authors reported that callus induction was dependent on the explant source (Passey et al., 2003 and Debnath 2005)

Table 3. Mean percentage of callus induction for three strawberry cultivars and four explants types on ten different media.

\begin{tabular}{|c|c|c|c|c|c|c|c|c|c|c|c|c|c|}
\hline \multirow{4}{*}{$\begin{array}{l}\text { Treat. } \\
\text { (M) }\end{array}$} & \multicolumn{12}{|c|}{ Cultivar (C) } & \multirow[b]{4}{*}{$\begin{array}{c}\text { Mean } \\
\text { (M) }\end{array}$} \\
\hline & \multicolumn{4}{|c|}{ Fortuna } & \multirow{2}{*}{\multicolumn{4}{|c|}{$\begin{array}{c}\text { Festival } \\
\text { Explant (E) }\end{array}$}} & \multirow{2}{*}{\multicolumn{4}{|c|}{ Sweet Charlie }} & \\
\hline & & & & & & & & & & & & & \\
\hline & Runner & Leaves & Anther & $\begin{array}{l}\text { Immatu } \\
\text { re fruit }\end{array}$ & Runner & Leaves & Anther & $\begin{array}{c}\text { Immat } \\
\text { ure } \\
\text { fruit }\end{array}$ & Runner & Leaves & Anther & $\begin{array}{l}\text { Immatu } \\
\text { re fruit }\end{array}$ & \\
\hline Control & 0.00[ & 0.0[ & 0.0[ & 0.0[ & 0.00[ & 0.00[ & 0.00[ & 0.00 & 0.00[ & 0.00[ & 0.00[ & 0.00[ & $0.0 \mathrm{j}$ \\
\hline MS 1 & $47.6 w-y$ & $93.8 \mathrm{a}-\mathrm{f}$ & $42.5 \mathrm{yz}$ & $33.75 z$ & $58.0 \mathrm{uv}$ & $56.3 \mathrm{u}-\mathrm{w}$ & $42.5 y z$ & $57.5 \mathrm{uv}$ & $45.0 x y$ & $56.7 \mathrm{uv}$ & $45.0 x y$ & $57.5 \mathrm{uv}$ & $53.00 \mathrm{i}$ \\
\hline MS 2 & $95.0 \mathrm{a}-\mathrm{d}$ & $90.5 a-h$ & $91.3 \mathrm{a}-\mathrm{h}$ & $71.3 \mathrm{q}-\mathrm{s}$ & $95.0 \mathrm{a}-\mathrm{d}$ & $90.7 \mathrm{a}-\mathrm{h}$ & $91.2 \mathrm{a}-\mathrm{h}$ & $73.7 \mathrm{o}-\mathrm{s}$ & $88.5 \mathrm{~b}-\mathrm{k}$ & $88.0 \mathrm{~b}-\mathrm{k}$ & $91.0 \mathrm{a}-\mathrm{h}$ & $73.7 \mathrm{o}-\mathrm{s}$ & $86.67 \mathrm{c}$ \\
\hline MS 3 & $94.0 \mathrm{a}-\mathrm{e}$ & $96.5 \mathrm{ab}$ & $82.5 \mathrm{~h}-\mathrm{o}$ & $75.8 \mathrm{n}-\mathrm{s}$ & $93.5 \mathrm{a}-\mathrm{f}$ & $96.5 a-b$ & 81.2i-p & $\underset{\mathrm{r}}{77.5 \mathrm{~m}-}$ & 87.0c-1 & $91.5 \mathrm{a}-\mathrm{g}$ & 81.2i-p & $78 m-q$ & $86.27 \mathrm{~d}$ \\
\hline MS 4 & $95.8 \mathrm{a}-\mathrm{c}$ & $91.8 \mathrm{a}-\mathrm{g}$ & $80.0 \mathrm{j}-\mathrm{q}$ & $\begin{array}{c}77.5 \mathrm{~m}- \\
\mathrm{r}\end{array}$ & 93.3a-f & $88.7 b-j$ & $80.0 \mathrm{j}-\mathrm{q}$ & $81.2 \mathrm{i}-\mathrm{p}$ & $83.7 \mathrm{~g}-\mathrm{n}$ & $87.5 \mathrm{c}-1$ & $79.7 \mathrm{k}-\mathrm{q}$ & $\begin{array}{c}85.0 \mathrm{f}- \\
\mathrm{m}\end{array}$ & $85.35 \mathrm{e}$ \\
\hline MS 5 & 88.8b-j & 91.3a-h & 93.8a-f & $67.5 \mathrm{st}$ & 86.3d-m & $90.5 \mathrm{a}-\mathrm{h}$ & $91.2 \mathrm{a}-\mathrm{h}$ & $68.7 \mathrm{r}-\mathrm{t}$ & 85.0f-m & $87.5 c-1$ & $92.5 \mathrm{a}-\mathrm{g}$ & $68.7 \mathrm{r}-\mathrm{t}$ & $77.44 \mathrm{f}$ \\
\hline MS 6 & $90.0 \mathrm{a}-\mathrm{i}$ & $92.5 \mathrm{a}-\mathrm{g}$ & 91.3a-h & $82.5 \mathrm{~h}-\mathrm{o}$ & $89.3 b-i$ & $90.7 \mathrm{a}-\mathrm{h}$ & $98.7 \mathrm{a}$ & $82.5 \mathrm{~h}-\mathrm{o}$ & $89.2 \mathrm{~b}-\mathrm{i}$ & $86.0 \mathrm{e}-\mathrm{m}$ & $92.5 \mathrm{a}-\mathrm{g}$ & $81.2 \mathrm{i}-\mathrm{p}$ & $95.57 \mathrm{a}$ \\
\hline MS 7 & 85.0f-m & 71.8q-s & $33.8 \mathrm{z}$ & $\begin{array}{c}77.5 \mathrm{~m}- \\
\mathrm{r}\end{array}$ & 85.0f-m & $72.5 \mathrm{p}-\mathrm{s}$ & $33.7 \mathrm{z}$ & $\begin{array}{c}77.5 \mathrm{~m}- \\
\mathrm{r}\end{array}$ & $82.5 \mathrm{~h}-\mathrm{o}$ & $71.7 \mathrm{q}-\mathrm{s}$ & $33.7 \mathrm{z}$ & 78.71-q & $66.958 \mathrm{~h}$ \\
\hline MS 8 & $90.0 \mathrm{a}-\mathrm{i}$ & $92.5 \mathrm{a}-\mathrm{g}$ & 93.8a-f & $73.80-\mathrm{s}$ & 90.3a-h & $92.5 \mathrm{a}-\mathrm{g}$ & $92.5 \mathrm{a}-\mathrm{g}$ & $73.7 \mathrm{o}-\mathrm{s}$ & $88.7 b-j$ & $89.3 b-i$ & $92.5 \mathrm{a}-\mathrm{g}$ & 75.0n-s & $87.042 \mathrm{~b}$ \\
\hline MS 9 & $77.5 \mathrm{~m}-\mathrm{r}$ & $61.5 \mathrm{tu}$ & $80.0 \mathrm{j}-\mathrm{q}$ & $57.5 \mathrm{uv}$ & 78.81-q & $57.7 \mathrm{uv}$ & $80.0 \mathrm{j}-\mathrm{q}$ & $57.5 u v$ & 78.751-q & $52.5 \mathrm{v}-\mathrm{x}$ & $80.0 \mathrm{i}-\mathrm{q}$ & $\begin{array}{c}56.2 \mathrm{u}- \\
\mathrm{w}\end{array}$ & $68.17 \mathrm{~g}$ \\
\hline $\begin{array}{l}\text { Mean C } \\
\text { Mean E }\end{array}$ & $75.38 \mathrm{a}$ & 71.2 & & $74.30 \mathrm{~b}$ & & & $\begin{array}{l}8 \mathrm{a} \\
68.98 \mathrm{c}\end{array}$ & & & $\begin{array}{r}69 . \\
64.08 \mathrm{~d}\end{array}$ & $b$ & & \\
\hline
\end{tabular}

Focusing on the effect of used media on callus formation, the obtained data in Table (3) revealed that significant differences among media were obtained. In this respect, MS6 (0.5 $\mathrm{mg} \mathrm{L}^{-1} \mathrm{BAP}+1.5 \mathrm{mg} \mathrm{L}^{-1} 2$, 4-D) produced 
the highest percentage (95.57\%) in comparison to other media including MS0 (control) which gave the least value. This may be attributed to the ratios of BAP to 2, 4-D that greatly affected callus induction. Similar results were recorded by Ara et al. (2012) who noted that the highest callus formation was MS medium containing with $1.0 \mathrm{mg} \mathrm{L}$

${ }^{1}$ 2, 4-D + $0.1 \mathrm{mg} \mathrm{L}^{-1}$ BAP using leaf (mature) derived explants. Also, Karim et al. (2011) found that there were specific ratio of auxin in combination with cytokinin (NAA BA) was the most effective for callus formation. Shamima et al. (2003) reported that concentrations of PGRS and selections are vital for strawberry callus induction.

As for the triple interaction effect, significant differences of callus formation percentage were obtained as shown in Table (3). Festival with anther and MS5 recorded the highest value, followed by Fortuna and festival with runner and MS3 (1.5 $\mathrm{mg} \mathrm{L}^{-1} 2,4-\mathrm{D}+$ $\left.0.2 \mathrm{mgL}^{-1} \mathrm{BAP}\right)$. On the other hand, no callus formation was observed in the control treatment (free hormone).

\section{Fresh weight of callus}

As for mean callus fresh weight in Table (4), there were insignificant differences between the tested cultivars.

In regard to the effect of explant type on callus fresh weight. data in Table (4) showed highly significant differences among explant types since immature fruit explants showed the highest value $(0.329 \mathrm{~g})$ followed by leaves $(0.260 \mathrm{~g})$, runners $(0.187 \mathrm{~g})$ and anther gave the lowest value $(0.027 \mathrm{~g})$.

Table 4. Mean callus fresh weight (g) for three strawberry cultivars and four explants types on ten different media.

\begin{tabular}{|c|c|c|c|c|c|c|c|c|c|c|c|c|}
\hline \multirow{4}{*}{$\begin{array}{l}\text { Treat. } \\
\text { (M) }\end{array}$} & \multicolumn{11}{|c|}{ Cultivar (C) } & \multirow{4}{*}{$\begin{array}{c}\text { Total } \\
\text { Mean } \\
\text { (M) }\end{array}$} \\
\hline & \multirow{2}{*}{\multicolumn{4}{|c|}{ fortuna }} & \multirow{2}{*}{\multicolumn{4}{|c|}{$\begin{array}{c}\text { Festival } \\
\text { Explant (E) }\end{array}$}} & \multirow{2}{*}{\multicolumn{3}{|c|}{ Sweet Charlie }} & \\
\hline & & & & & & & & & & & & \\
\hline & Runner & Leaves & Anther & $\begin{array}{l}\text { Immatu- } \\
\text { re fruit }\end{array}$ & Runner & Leaves & Anther & $\begin{array}{r}\text { Immatu - } \\
\text { re fruit }\end{array}$ & Runner & Leaves Anther & $\begin{array}{c}\text { Immatu-re } \\
\text { fruit }\end{array}$ & \\
\hline control & $0.00 \mathrm{x}$ & $0.00 \mathrm{x}$ & $0.00 \mathrm{x}$ & $0.00 \mathrm{x}$ & $0.00 \mathrm{x}$ & $0.00 \mathrm{x}$ & $0.00 \times$ & $0.00 \mathrm{x}$ & $0.00 \mathrm{x}$ & $0.00 \times 0.00 \times$ & $0.00 \mathrm{x}$ & $0.00 \mathrm{e}$ \\
\hline & & 0.17 & $0.03 \mathrm{u}-\mathrm{x}$ & & & & & & & $0.17 \mathrm{p}-\mathrm{x} 0.02 \mathrm{wx}$ & & \\
\hline MS 2 & & $0.145 q-x$ & $0.03 \mathrm{u}-\mathrm{x}$ & $0.44 \mathrm{~b}-\mathrm{g}$ & $0.28 \mathrm{~g}-\mathrm{t}$ & $0.25 \mathrm{~g}-\mathrm{t}$ & $0.04 \mathrm{u}-\mathrm{x}$ & 0.39 & $0.45 b-f$ & $0.22 \mathrm{j}-\mathrm{u} 0.02 \mathrm{wx}$ & 0.36 & $0.231 \mathrm{a}-\mathrm{d}$ \\
\hline MS 3 & $0.162 q-x$ & $0.175 \mathrm{o}-\mathrm{x}$ & $0.02 \mathrm{wx}$ & $0.49 \mathrm{a}-\mathrm{d}$ & 0.207 & $0.30 \mathrm{e}-\mathrm{t}$ & $0.03 \mathrm{v}-\mathrm{x}$ & $0.44 b-f$ & $0.53 \mathrm{a}-\mathrm{c}$ & $0.20 \mathrm{l}-\mathrm{w} \quad 0.05 \mathrm{u}-\mathrm{x}$ & $0.26 \mathrm{f}-\mathrm{t}$ & $0.239 \mathrm{a}-\mathrm{c}$ \\
\hline & & & $0.03 \mathrm{u}$ & & & $0.290 \mathrm{e}-\mathrm{t}$ & $0.03 \mathrm{v}$ & & & $0.15 \mathrm{q}-\mathrm{x} 0.04$ & & \\
\hline MS 5 & & $0.250 \mathrm{~g}-\mathrm{t}$ & $0.04 \mathrm{c}$ & 0.47 & & $0.28 \mathrm{f}-\mathrm{t}$ & 0.03 & & 0.33 & $0.14 \mathrm{r}-\mathrm{x} \quad 0.04 \mathrm{u}-\mathrm{x}$ & & 0.24 \\
\hline & & & $0.02 \mathrm{v}$ & & & $0.36 \mathrm{c}-\mathrm{o}$ & 0.02 & & & $0.15 q-x 0.0$ & & \\
\hline & & $0.135 \mathrm{~s}-\mathrm{x}$ & $0.03 \mathrm{v}$ & 0 & & $17 \mathrm{p}-\mathrm{x}$ & 0.03 & $0.37 \mathrm{c}-\mathrm{n}$ & 0.27 & $0.27 \mathrm{f}-\mathrm{t} \quad 0.02$ & & 0.19 \\
\hline MS 8 & $.017 \mathrm{p}-\mathrm{x}$ & $0.160 q-x$ & $0.04 \mathrm{u}-\mathrm{x}$ & $0.33 \mathrm{~d}-\mathrm{q}$ & 0.410 & $0.31 \mathrm{~d}-\mathrm{t}$ & $0.04 \mathrm{u}-\mathrm{x}$ & $0.56 \mathrm{ab}$ & $0.18 \mathrm{n}-\mathrm{x}$ & $0.17 \mathrm{p}-\mathrm{x} \quad 0.03 \mathrm{u}-\mathrm{x}$ & $0.31 \mathrm{~d}-\mathrm{t}$ & $0.225 \mathrm{bcd}$ \\
\hline MS 9 & & $0.140 \mathrm{r}-\mathrm{x}$ & $0.02 \mathrm{wx}$ & $0.32 \mathrm{~d}-\mathrm{s}$ & 0.252 & $0.18 \mathrm{q}-\mathrm{x}$ & $0.04 \mathrm{u}-\mathrm{x}$ & $0.31 \mathrm{~d}-\mathrm{t}$ & $0.27 \mathrm{f}-\mathrm{t}$ & $0.14 \mathrm{q}-\mathrm{x} \quad 0.02 \mathrm{wx}$ & $0.27 \mathrm{f}-\mathrm{t}$ & $0.190 \mathrm{~d}$ \\
\hline & & \multirow{2}{*}{\multicolumn{2}{|c|}{$0.185 \mathrm{~b}$}} & & & \multirow{2}{*}{\multicolumn{2}{|c|}{$0.217 \mathrm{a}$}} & & & & & \\
\hline Mean E & $0.260 \mathrm{~b}$ & & & & $0.187 \mathrm{c}$ & & & $0.027 \mathrm{~d}$ & & & $0.329 \mathrm{a}$ & \\
\hline
\end{tabular}

Means followed by the different letter (s) in the same collum are significantly different by Duncan's Multiple Range at the probability of $5 \%$.

With respect to the effect of media on callus fresh weight, significant differences were found. MS6 $\left(1.5 \mathrm{mg} \mathrm{L}^{-1}\right.$ 2 , 4-D + $\left.0.5 \mathrm{mg} \mathrm{L}^{-1} \mathrm{BAP}\right)$ medium gave the maximum weight followed by MS5 (1.0 mg L ${ }^{-1} 2$, 4-D + $0.5 \mathrm{mg} \mathrm{L}^{-1}$ BAP), MS3 (1.5 $\mathrm{mg} \mathrm{L}^{-1} 2$, 4-D + 0.2 $\left.\mathrm{mg} \mathrm{L}^{-1} \mathrm{BAP}\right)$ and MS2 (1.0 $\mathrm{mg} \mathrm{L}^{-1} 2$, 4-D + 0.2 $\mathrm{mg} \mathrm{L}^{-1}$ BAP). While, MS9 (1.5 mg $\left.\mathrm{L}^{-1} 2,4-\mathrm{D}+1 \mathrm{mg} \mathrm{L}^{-1} \mathrm{BAP}\right)$ gave the lowest value .Other media exhibited intermediate values.

As for the triple interaction effect, the results demonstrated significant differences of callus fresh weight, as the Sweet Charlie cultivar with runner and MS6 showed the maximum value. Moreover, the other media exhibited intermediate values.

\section{Regeneration stage:}

Plant genotype, explant types, basal culture media and PGRs (table 2) concentrations, significantly influenced shoot regeneration $\%$, shoot number and shoot length.

\section{Regeneration percentage (\%)}

In regard to the effect of tested cultivars on percentage of regeneration, Table (5) illustrated that significant difference were detected. Fortuna cultivar had a tendency in increasing this percentage $(27.081 \%)$, followed by Festival (26.113\%), while Sweet Charlie gave the least value $(24.275 \%)$. These results proved that genotype had a vital role in shoot organogenesis. The same trend was recorded by Passey et al. (2003) and Landi and Mezzetti (2006), who reported that shoot organogenesis differs among different studied genotypes.

The obtained data as shown in Table (5) and photo (2), revealed that significant differences were found among explant types. This percentage was higher in runner explants $(57.82 \%)$ than other organs. In this sphere, anther did not give regeneration. In the same line; many other authors reported that shoot organogenesis was dependent on the explant source (Passey et al., 2003 and Debnath 2005).

Concerning the effect of used media on regeneration, there were highly significant differences were detected (Table 5). Using $2.0 \mathrm{mg} \mathrm{L}^{-1}$ BAP whether alone or with the high concentration of NAA $(0.5 \mathrm{mg}$ $\mathrm{L}^{1}$ ) in the MSR8 and MSR5 media, respectively, enhanced the percentage of regeneration in comparison to other media. This could be attributed to the role of cytokinin and Auxin in promoting cell division and elongation (Mok and Mok 2001). Similar results were obtained by Ara et al. (2012) and Mahmoud and Moradi (2013) reported that the media consist from $2.0 \mathrm{mg} \mathrm{L}^{-1}$ BAP plus $0.5 \mathrm{mg} \mathrm{L}^{-1} \mathrm{NAA}$ was the best for shoot regeneration.

As for the triple interaction effect, the results exhibited that using runner as explant source and MS8 (2.0 $\mathrm{mg} \mathrm{L}^{-1}$ BAP) with the three tested cultivars recorded highly significant regeneration percentage in comparison to other combinations. These results are in agreement with those of Sheeja et al. (2004), Gubis et al. (2004) and Chaudhry et al. (2004) who reported that the frequency of adventitious shoot regeneration differed depending on the type of explants and the concentration of PGRs added to the regeneration medium. In addition, Devi et al. (2008) observed statistically significant differences in regeneration capacity between four genotypes. 
Dawa, K. K. et al.
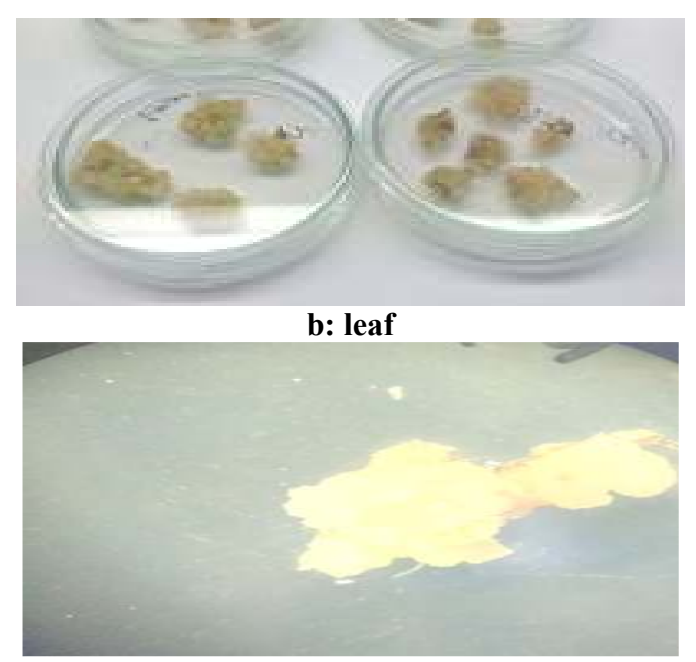

a: ruuner

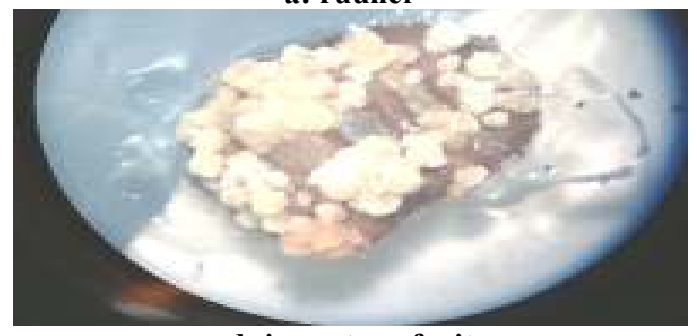

d: immature fruit

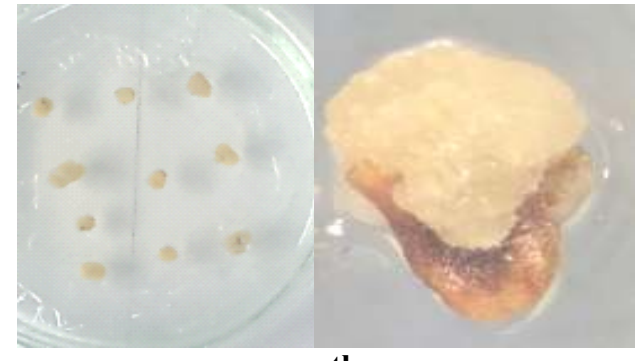

c: anther

Photo 1. callus induction from four explant types.

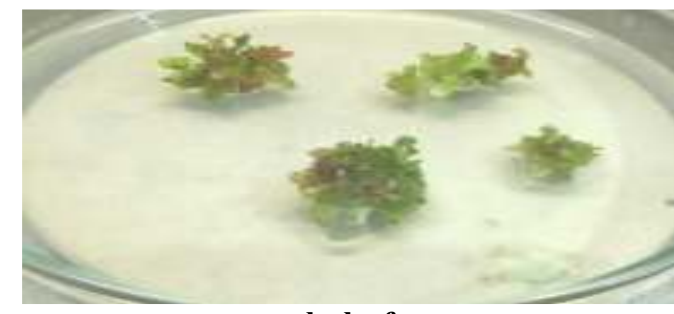

b: leaf

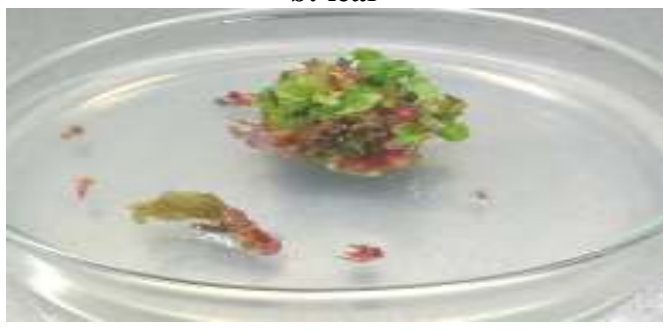

a: runner

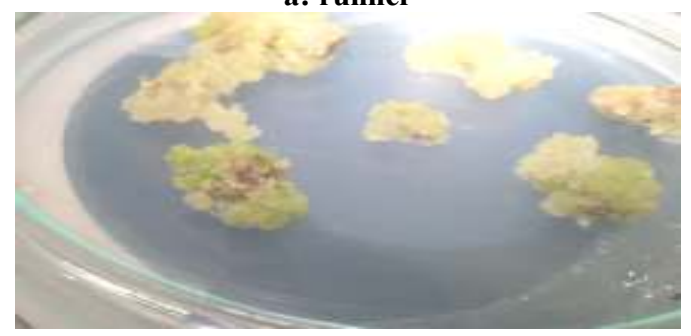

d: anther

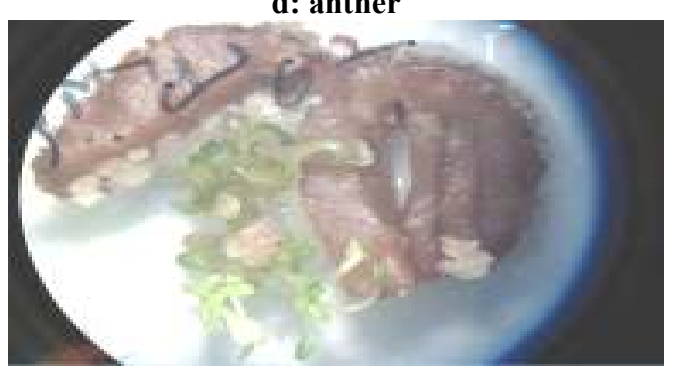

c:immature fruit

Photo 2. Shoot regeneration from different explant types

Table 5. Mean regeneration percentage per explant for three strawberry cultivars and four explants types on ten different media.

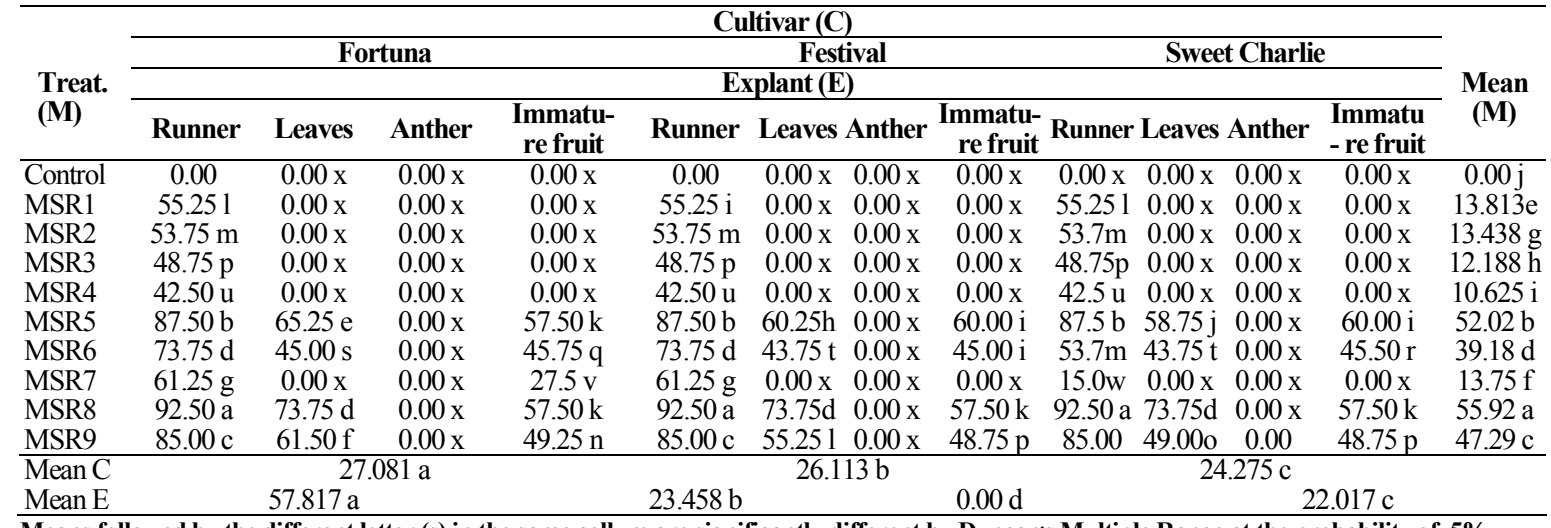

Means followed by the different letter ( $(s)$ in the same collum are significantly different by Duncan's Multiple Range at the probability of $5 \%$.

Number of shoots per explant by Festival, while the least number was produced by Sweet

The mean number of shoots per explant for three Charlie. Gubiš et al. (2003) observed statistically significant strawberry cultivars, four types of explant and ten different differences in regeneration ability between genotypes and media are presented in Table (6). The obtained data revealed significant differences among the tested cultivars. The cultivar fortuna gave the highest number of shoots, followed

between explant types.

As for the effect of explant types regardless of genotype, the obtained data revealed highly significant 
differences among explant types. Since runner explants showed the highest value, followed by leaves and immature fruit. It could be explained by the fact that hormone content varies among vegetative organs.

Regarding the media effect, The Table (6) evinces that the highest significant number of shoots per explant were produced by MSR5 $\left(2.0 \mathrm{mgL}^{-1} \mathrm{BAP}+0.5 \mathrm{mgL}^{-}\right.$ $\left.{ }^{1} \mathrm{NAA}\right), \mathrm{MSR} 8$ (2.0 $\left.\mathrm{mgL}^{-1} \mathrm{BAP}\right), \mathrm{MSR} 6$ (3.0 mgL ${ }^{-1} \mathrm{BAP}+$ $\left.0.5 \mathrm{mgL}^{-1} \mathrm{NAA}\right)$ in descending order, while MSR1(1.0 $\mathrm{mgL}^{-}$

Table 6. Mean number of shoots per explant for strawberry cultivars and explants types on ten different media.

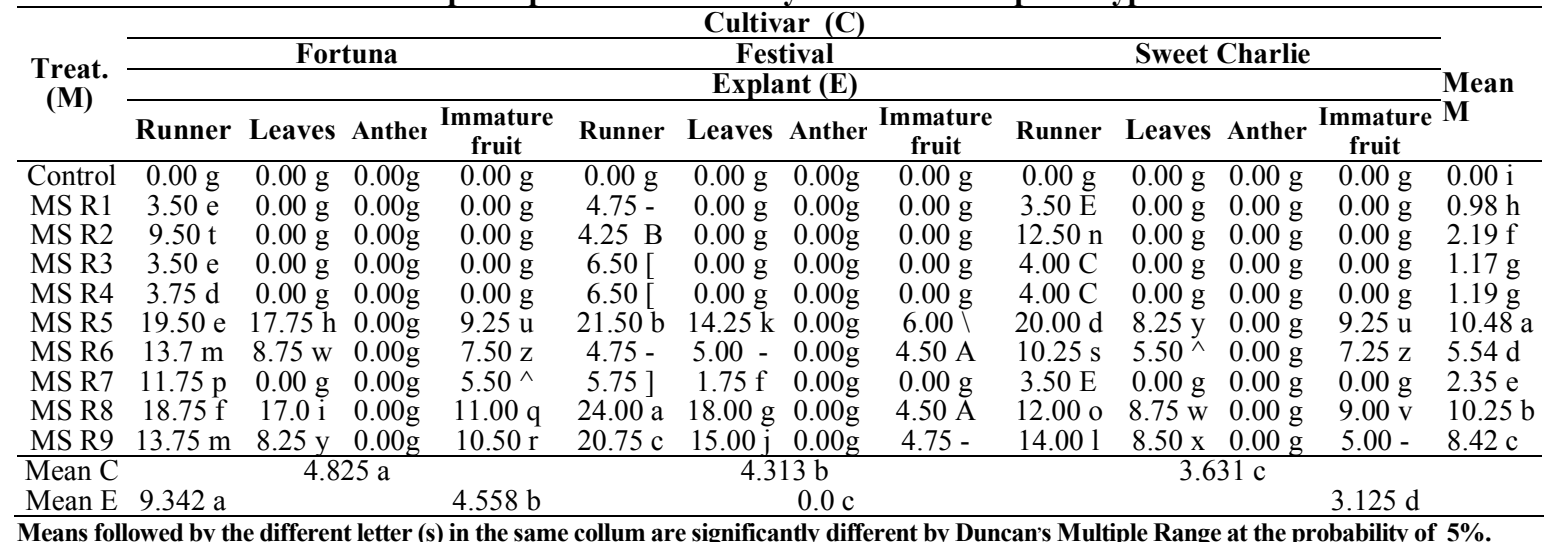

The triple response effect among the explant source, media and cultivars on number of shoots, significant differences among all combinations were obtained, runner was taken from Festival cultivar with MSR8 produced higher number than other combinations (as shown in Table 6).

\section{Shoot length per explant}

The mean shoot length per explant for the three strawberry cultivars and four explant types cultured on ten different media are presented in Table (7). The
${ }^{1} \mathrm{BAP}+0.1 \mathrm{mgL}^{-1} \mathrm{NAA}$ ) gave the lowest values. Other media recorded intermediate values. These results are also in line with Ara et al. (2012) who found that the highest number of shoot per inoculum was obtained in MS medium containing $2.0 \mathrm{mg} \mathrm{L}^{-1} \mathrm{BAP}+0.5 \mathrm{mg} \mathrm{L}^{-1} \mathrm{NAA}$. Also Rajbhar et al. (2016) found that the maximum number of shoots per explant was recorded at $2 \mathrm{mg} \mathrm{L}^{-1} \mathrm{BA}+1.5 \mathrm{mg} \mathrm{L}^{-1} \mathrm{IBA}$

Table 7. Mean shoot length per explant for three strawberry cultivars and four explants types on ten different media.

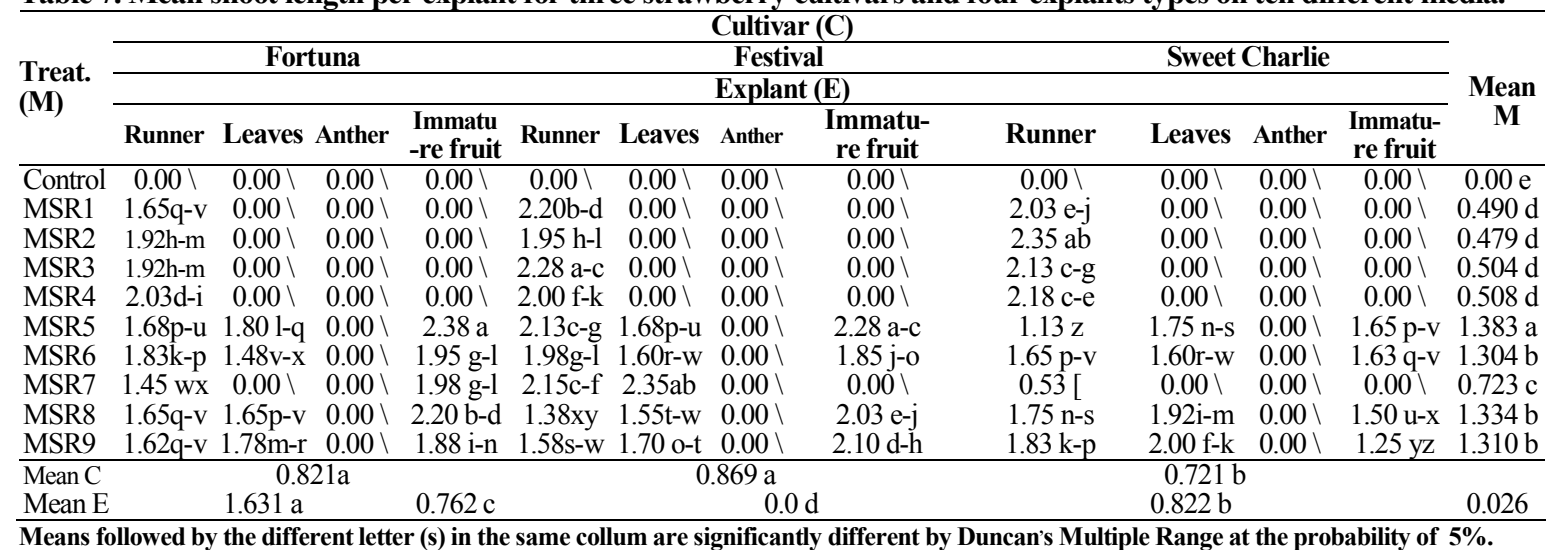

Regarding the used media, the results revealed that significant differences among media. In this respect, MSR5 (2.0 $\left.\mathrm{mg} \mathrm{L}^{-1} \mathrm{BAP}+0.5 \mathrm{mg} \mathrm{L}^{-1} \mathrm{NAA}\right)$ produced the highest shoot length $(1.383 \mathrm{~cm})$ in comparison to other media. Control did not give regeneration. Similar results were obtained by Bhatt and Dhar (2000) on strawberry who reported that BAP enhanced elongation of shoot.

With reference to the triple combination effect on shoot length, immature fruit from Fortuna cultured onto obtained data revealed that there were significant differences among the tested cultivars. Festival and Fortuna cultivars recorded higher significant values of shoot length than Sweet Charlie.

Regarding the effect of four explants irrespective of cultivars on shoot length, significant differences among explant types were observed as Table (7). Runner explants exhibited the highest value, followed by immature fruit and leaves. $5.0 \mathrm{mg} \mathrm{L}^{-1} \mathrm{BAP}+0.2 \mathrm{mgL}^{-1} \mathrm{NAA}$ (MSR5) registered
the highest significant shoot length.

\section{REFERENCES}

Ara, t.; R. Karim; M. R. Karim; R. Islam and M. Hossain (2012). Callus induction and shoot regeneration in strawberry (Fragaria $\mathrm{x}$ ananassa Duch.). International Journal of Biosciences, 2,10(1): 93-100.

Bhatt, I. D. and U. Dhar (2000). Micropropagation of indian wild strawberry. Plant Cell, Tissue and Organ Culture, 60: 83-88. 
Biswas, M.; U. K. Roy; R. Islami and M. Hossain (2010). Callus culture from leaf blade, nodal, and runner segments of three strawberry (Fragaria sp.) clones. Turk. J. Biol., 34: 75-80.

Chaudhry, Z.; A. Afroz and H. Rashid and A. S. Qureshi (2004). Regeneration from explants of in-vitro seedlings of tomato (lycopersicion esculentum Mill., cv.Roma). paj. J. of Biol. Sci., 7(2): 269-272.

Duncan, D. B. (1965). Multiple range and multiple Ftest. Biometrics, 11: 1-42

Debnath, C. S. (2005).Strawberry sepal: Another explant for thidiazuron-induced adventitious shoot regeneration. In Vitro Cell. Dev. Biol. Plant, 41: 671-676.

Devi, M.; M. S. Dhaliwal; A. kaur and S. S. Gosal (2008). Effect of growth regulators on in vitro morphogenetic response of tomato. Indian Journal of Biotechnology, 7: $526-530$

FAOSTAT (2014). Searchable online statistical database from Food and Agriculture Division of the United Nations.

Gaafar, R. M. and M. M. Saker (2006). Monitoring of cultivars identity and genetic stability in strawberry varieties grown in Egypt. World Journal of Agricultural Sciences, 2 (1): 29-36.

Giampieri, F.; J. M. Alvarez-Suarez and M. Battino (2015). Strawberry and human health: Effects beyond antioxidant activity. Journal of Agriculture and Food Chemistry, 62: 3867-3876.

Gubiŝ, J.; Z. Lajchová; J. farragó and Z. Jureková (2004). Effect of growth regulators on shoot induction and plant regeneration in tomato (lycopersicion esculentum Mill.). Biologia, Bratislava, 59(3): 405408.

Karim, M. R.; M. A. Aziz; U. K. Roy; M. A. Hoque and M. M. Hossain (2011). In vitro response of strawberry (Fragaria $\mathrm{x}$ ananassa Dutch.) for callus induction and shoot regeneration. Inter. J. of Agron. and Agric. Res., 1(1): 29-36.

Karim, R.; F. Ahmed; U. K. Roy; T. Ara; R. Islam and M. Hossain (2015). Varietal improvement of strawberry (Fragaria $\mathrm{x}$ ananassa Dutch.) through somaclonal variation using in vitro. J. Agric. Sci. Tech., 17: 977986.
Landi, L. and B. Mezzetti (2006). TDZ, auxin and genotype effects on leaf organogenesis in Fragaria. Plant Cell Rep., 25: 281-288.

Mok, D. W. S. and M.C. Mok (2001). Cytokinin metabolism and action. Annual Review of Plant Physiology and Plant Molecular Biology, 52, 89118.

Mahmoud, O. and K. Moradi (2013). Regeneration and Histological of Plants Derived from Leaf explants in vitro Culture of Strawberry. International Journal of Agriculture and Crop Sci., 5 (9): 943-950.

Murashige T. and F. Skoog (1962). A revised medium for rapid growth and bio-assays with tobacco tissue cultures. Physiol. Plant, 15(3): 473-497.

Passey, A.; K. Barrett and D. James (2003). Adventitious shoot regeneration from seven commercial strawberry cultivars (Fragaria $\times$ ananassa Duch.) using a range of explant types. Plant Cell Replication, 21:397-401.

Pierik, R. L. M.(1987) In vitro culture of higher plants. Martinus Nijhoff. Dordrecht, Boston, Lancaster. pp. 364-370.

Rajbhar, Y. P.; S. Tomar; H. Katiyar; M. Kumar; A. Kumar and G. Rajbha (2016). Effect of cytokinin and auxin on callus formation and shoot multiplication of strawberry (Fragaria $x$ ananassa Duch.) under in vitro condition. Hort Flora Res. Spectrum, 5(3): 206-212.

Shamima N.; M. M. Hossain; A. Khatun; A. Alam and M. R. Mondal (2003). Induction and evaluation of somaclonal variation in potato (Solanum tuberosum L.) Inl. J. Biol. Sci., 3(2): 183- 190.

Sheeja, T.; E. A. Mondal and R. K. Rathore (2004). Efficient plantlet regeneration in tomato (lycopersicion esculentum mill.). plant Tissue Cult., 14: 45-53

Sutan, A. N. (2010). The regenerative capacity of the callus in two genotypes of ornamental strawberry. Muzeul Olteniei Craiova. 26 (1): 29-33.

Sutan, A. N.; A. Popescu and V. Isac (2010). In vitro culture medium and explant type effect on callogenesis and shoot regeneration in two genotypes of ornamental strawberry. Romanian Biotechnological Letters, 15(2):12-18.

\footnotetext{
تأثير كل من منظمات النمو والجزء التباتى على انتاج الكالس واعادة تكوين الافرع فى ثلاثة اصناف من القراولة.

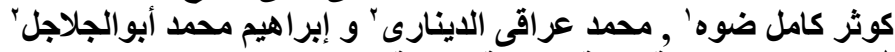

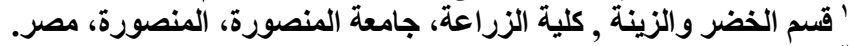

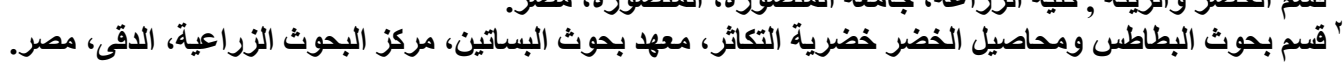

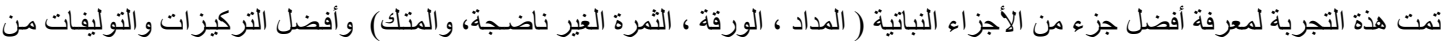

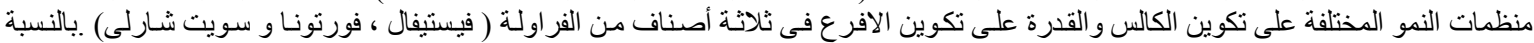

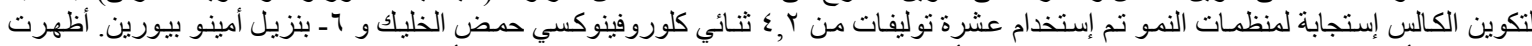

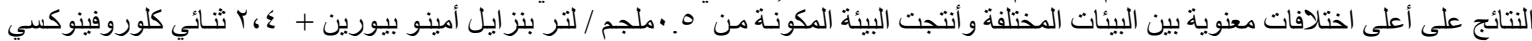

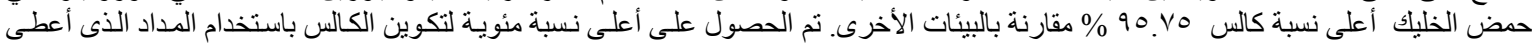

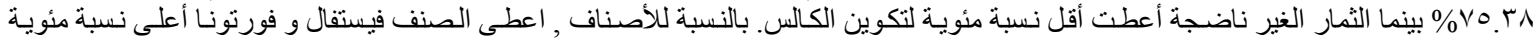

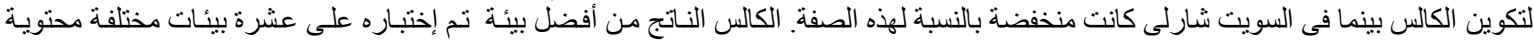

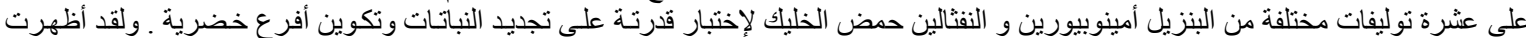

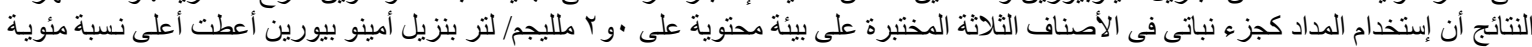

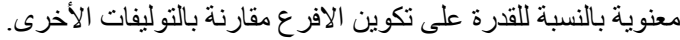

